\title{
Nutritional supplementation to prevent and slow the progression of chronic kidney disease: focus on bicarbonate
}

This article was published in the following Dove Press journal:

Nutrition and Dietary Supplements

29 June 2010

Number of times this article has been viewed

\author{
Vahan Koshkaryan' \\ Albert Yuh-Jer Shen² \\ Roxana Mehran ${ }^{3}$ \\ Prakash Mansukhani ${ }^{4}$ \\ Somjot S Brar ${ }^{4,5}$ \\ 'Department of Internal Medicine, \\ ${ }^{2}$ Division of Cardiology, Kaiser \\ Permanente, Los Angeles, CA, USA; \\ ${ }^{3}$ Columbia University Medical Center, \\ New York, NY, USA; ${ }^{4}$ Regional \\ Cardiac Catheterization Laboratory, \\ Kaiser Permanente, Los Angeles, \\ CA, USA; ${ }^{5}$ Department of Research \\ and Evaluation, Kaiser Permanente, \\ Pasadena, CA, USA
}

\begin{abstract}
Sodium bicarbonate is an important buffer in the maintenance of acid/base homeostasis. It plays an important role in preventing acidemia and associated complications. Among patients with chronic kidney disease, metabolic acidosis has been linked to disorders of muscle and bone metabolism. Administration of sodium bicarbonate can largely correct these abnormalities. More recently, the use of sodium bicarbonate for the prevention of contrastmedium induced nephropathy has generated considerable interest. Contrast induced nephropathy is a common complication of iodinated contrast media exposure in patient with chronic kidney disease. There are now multiple randomized controlled trials comparing sodium bicarbonate to sodium chloride among patients with chronic kidney disease. However, the results of these trials are not conclusive on the efficacy of sodium bicarbonate hydration for the prevention of contrast nephropathy. In this review, we discuss the role of sodium bicarbonate treatment in chronic kidney disease with an emphasis on prevention of contrast induced nephropathy. Insights gained from randomized trials and meta-analyses are discussed.
\end{abstract}

Keywords: sodium bicarbonate, chronic kidney disease, contrast induced nephropathy

\section{Introduction}

Sodium bicarbonate is an important buffer in the maintenance of acid/base homeostasis. It plays an important role in preventing acidemia and associated complications. ${ }^{1}$ Among patients with chronic kidney disease (CKD), metabolic acidosis has been linked to disorders of muscle and bone metabolism..$^{2-4}$ Administration of sodium bicarbonate can largely correct these abnormalities.

More recently, sodium bicarbonate has been evaluated for the prevention of contrastmedium induced nephropathy (CIN). In susceptible individuals, CIN occurs after exposure to iodinated contrast media. It is a common complication in patients with CKD and is the most frequent cause of iatrogenic acute kidney injury. ${ }^{5}$ Persons with CKD stage III or greater (glomerular filtration rate [GFR] $<60 \mathrm{~mL} / \mathrm{min}$ per $1.73 \mathrm{~m}^{2}$ ) are considered to be at the greatest risk for CIN ${ }^{6-8}$ With the increasing prevalence of CKD and diagnostic and interventional procedures utilizing contrast-media, the incidence of CIN is likely to increase further. ${ }^{9}$ The higher morbidity, mortality, and healthcare expenditure resulting from CIN have led to numerous investigations into preventive therapies. In this review, we discuss the use of sodium bicarbonate supplementation in the patient with CKD, in particular for the prevention of CIN. Randomized trials of sodium bicarbonate therapy are reviewed with an emphasis on their strengths and limitations.
Correspondence: Somjot S Brar

Director of Vascular Medicine, Kaiser Permanente, 4867 Sunset Blvd, 3rd Floor, Cardiac Catheterization Lab, Rm 3755 Los Angeles, CA 90027, USA

Tel + I 3237834079

$\mathrm{Fax}+$ I 3233378352

Email sbrar@cvri.org 


\section{Normal physiology of acid/base homeostasis}

In the healthy individual, the kidneys help maintain acid/base homeostasis to prevent the complications seen in acidemia or alkalemia. The initial phase of maintaining balance is the absorption of bicarbonate. Since loss of bicarbonate is equivalent to an equal gain in acid in the bloodstream, all of the bicarbonate that is filtered must initially be reabsorbed. Once this is complete, any excess acid can then be excreted in the urine. $\mathrm{H}+$ is initially secreted in the proximal tubule and the loop of Henle through a passive Na-H exchanger. Distally, the collecting tubules are able to actively excrete $\mathrm{H}+$ through an aldosterone responsive $\mathrm{H}$-ATPase.$^{10}$ However, free $\mathrm{H}+$ cannot be excreted and therefore buffers must exist. Some of the $\mathrm{H}+$ binds to filtered buffers such as HPO4(2-) and creatinine but the main mechanism of excretion is through the formation of ammonium. Glutamine is metabolized in the proximal tubule to form ammonia which is then secreted and binds to the free $\mathrm{H}+$ to form ammonium which is then excreted in the urine. Precise control of the acid/base homeostasis requires a very complex process involving many mechanisms that must operate optimally. Any malfunction of the corresponding mechanisms, such as that occurs in the many forms of CKD, can lead to a disruption in the acid/base homeostasis in the body.

\section{Metabolic acidosis in CKD and associated complications}

$\mathrm{CKD}$ is a general term that applies to many different forms of renal impairment secondary to a variety of etiologies, including diabetes, the many glomerulonephritides, hypertension (HTN), drug-induced, and others. It is very common in the United States with an increasing number of diagnoses yearly. ${ }^{9,11}$ With the growing number of patients with CKD come the many complications associated with it such as metabolic acidosis. It has been estimated that 300-400,000 patients have metabolic acidosis in the United States and the prevalence among CKD patients in some studies is as high as $60 \% .{ }^{9}, 12$

The metabolic acidosis of CKD is a result of the reduced capacity of the kidneys to make ammonium and subsequently excrete $\mathrm{H}+{ }^{13}$ Decreased ability of the proximal tubule to uptake glutamine leads to decreased ammonia production and secretion making the kidneys reliant on titratable acid excretion. ${ }^{14}$ Metabolic acidosis is also a result of decreased production of new bicarbonate and to a lesser extent decreased bicarbonate reabsorption. ${ }^{14,15}$ There is no evidence of increased endogenous production of hydrogen ion in $\mathrm{CKD}$, therefore the metabolic acidosis is a result of pathology at the renal level. ${ }^{16}$ The resulting acidosis leads to serum bicarbonate levels of $12-22$ in CKD. ${ }^{17}$ The bicarbonate levels generally do not drop below 12 and metabolic acidosis becomes more common in patients whose GFR is below $30 \mathrm{~mL} / \mathrm{min}$ per $1.73 \mathrm{~m}^{2} .{ }^{18}$

The metabolic acidosis caused by CKD leads to several complications. ${ }^{1}$ Of these, the most common relates to nutritional status as well as protein metabolism. Metabolic acidosis may lead to protein energy wasting (PEW) disorder and has been linked with increased protein catabolism through the upregulation of the ubiquitin-proteosome system, excessive oxidation of branched-chain amino acids, and decreased synthesis of proteins like albumin. ${ }^{19-23} \mathrm{~A}$ study in rats showed that metabolic acidosis causes increased protein degradation. ${ }^{24}$ In patients whose bicarbonate levels are less than 15 , as much as $30 \mathrm{~g}$ of protein may be lost in a day. ${ }^{20}$ Protein breakdown is also contributed to by increased glucocorticoid levels stimulated by the metabolic acidosis. ${ }^{1}$ Leal et al showed that muscle and fat mass wasting is higher in acidotic patients. ${ }^{25}$ Several other studies have shown a strong relationship between bicarbonate levels and hypoalbuminemia especially when bicarbonate levels fall below 22, and there is a direct association between higher bicarbonate levels and increased albumin. ${ }^{26,27}$ The NHANES III study confirmed that hypoalbuminemia is indeed associated with low bicarbonate levels in CKD patients. ${ }^{28}$ Even in normal renal function, metabolic acidosis decreases albumin synthesis. ${ }^{20}$

Metabolic acidosis has also been associated with bone disorders. The acidosis stimulates bone resorption and inhibits bone formation, inhibits vitamin D production, and stimulates parathyroid hormone (PTH) production and responsiveness., ${ }^{3,29-33}$ There is a direct suppression by acidosis on osteoblast induced collagen synthesis and therefore bone formation. ${ }^{29}$ Metabolic acidosis also directly stimulates osteoclastic function leading to increased bone resorption. ${ }^{3,29}$. There is also an independent increase in PTH levels, as well as enhanced action of the PTH due to the acidic $\mathrm{pH}$, which stimulates osteclastic activity. ${ }^{30}$ The breakdown of bone acts to buffer the extra acid, however it contributes to the renal osteodystrophy common in CKD.

Worsening of renal function has also been observed with the metabolic acidosis of CKD. In rats metabolic acidosis has been linked with the development and worsening of proteinuria and tubulointerstitial fibrosis as well as the accelerated decline in renal function. ${ }^{34-37}$ In a study by Gennari et al there was a direct correlation between GFR levels and bicarbonate levels. ${ }^{38}$ Leal et al also showed that the average creatinine clearance $(\mathrm{CrCl})$ was lower in patients with metabolic acidosis and that $50 \%$ of patients with $\mathrm{CrCl}<60$ had some level of acidosis. ${ }^{25}$ One of the theories behind the worsening renal 
function secondary to metabolic acidosis is its association with inflammatory mediators. ${ }^{13,39}$. Metabolic acidosis may lead to increased tumor necrosis factor (TNF)-alpha production which is a very potent mediator. ${ }^{40}$ Therefore the worsening of renal function may be secondary to the activation of complement pathways leading to further damage. ${ }^{35}$ This effect causes a spiral of worsening acidosis secondary to renal damage and resulting renal damage secondary to the worsening acidosis, eventually culminating in end stage renal disease (ESRD).

Metabolic acidosis has also been implicated in other complications. It can worsen cardiac disease by leading to apoptosis of cardiac cells and increased aldosterone production can be harmful especially in patients with congestive heart failure (CHF). ${ }^{41,42}$ Metabolic acidosis also leads to decreased insulin sensitivity secondary to reduced insulin binding to receptors and consequently impaired glucose tolerance. ${ }^{43}$ Since cardiac disease and diabetes are already the two common comorbidities of $\mathrm{CKD}$, the acidosis may lead to difficulties in managing these coexisting conditions. Decreased thyroxine levels and elevated thyroid-stimulating hormone (TSH) indicating thyroid dysfunction may also be caused by metabolic acidosis. ${ }^{44}$ With so many body systems affected, it is no surprise that metabolic acidosis has been associated with increased mortality. In the Dialysis Outcomes and Practice Patterns Study (DOPPS) of hemodialysis patients, severe acidosis (serum bicarbonate level $<17$ ) was associated with increased mortality and hospitalization, although mild acidosis with bicarbonate levels around 20-21 had lower mortality than if $>27 .{ }^{45}$ Also, a study by Kovesdy et al showed higher mortality in patients with bicarbonate levels $<22$ (multivariable adjusted hazard ratio $1.33, P<0.02) .{ }^{46}$

\section{Administration of bicarbonate in CKD}

Due to evidence showing the deleterious effects of metabolic acidosis, several studies have tested the possible advantageous effects of administering bicarbonate to patients with CKD. For example, the correction of metabolic acidosis with oral bicarbonate has been shown to decrease protein catabolism. ${ }^{47}$ Also, maintaining a bicarbonate level between 22-26 was shown to significantly decrease the rise in blood urea nitrogen (BUN) levels and increase self reported patient well-being in $50 \%$ of patients. ${ }^{48}$ Oral bicarbonate administration has even been shown to improve stunted growth and the healing of bones in children. ${ }^{49,50}$

A recent study demonstrated the benefits of administering sodium bicarbonate in patients with CKD. ${ }^{51}$ The study compared the rate of decline of $\mathrm{CrCl}$ in patients treated to bicarbonate levels between 16-20 with patients with no correction. The study showed that at 1 year, the decline of $\mathrm{CrCl}$ was similar, although this was most likely secondary to the dropout of patients in the control group who had a rapid decline in $\mathrm{CrCl}$ or developed ESRD. At 2 years, $\mathrm{CrCl}$ in the control group decreased by 5.93 compared to 1.88 in the treatment group with $45 \%$ of the control group having a rapid decline defined as greater than 3 units per year, compared with $9 \%$ in the treatment group (relative risk [RR]: $0.15, P<0.0001)$. Fewer patients developed ESRD requiring dialysis $(\mathrm{CrCl}<10), 6.5 \%$ compared to $33 \%(\mathrm{RR}$, $0.13 ; P<0.001)$ and although there were more patients who developed ESRD in the control group, the rate of decline in $\mathrm{CrCl}$ was still significantly higher than in the treatment group in the remaining patients. The study also showed that although there was increased sodium intake, there was no significant difference in blood pressure control or increased edema. Dietary protein intake and decreased normalized protein nitrogen appearance were both increased leading to greater lean body mass and mid-arm muscle circumference $(P<0.03)$. Also patients in the treatment group had higher serum albumin levels and decreased potassium levels.

\section{Administration of bicarbonate in ESRD}

The administration of bicarbonate in ESRD has also been shown to be beneficial. Bicarbonate can be administered orally or by increasing the concentration in the dialysate fluid. In a Cochrane review of three studies in 2009, two in patients on hemodialysis and one in patients on peritoneal dialysis, there was improvement in nutritional status and protein metabolism as well as significant decrease in serum PTH and reduction in bone turnover. ${ }^{52}$ The studies were also able to show no difference in sodium or blood pressure levels. Only one trial reported clinical outcomes. ${ }^{53}$ In this study the rate of hospitalization, average length of hospital stay, and all-cause mortality were nonsignificantly in favor of sodium bicarbonate supplementation. In aggregate, there were 117 patients in these three trials. The small size of the trials, short duration of follow-up, and lack of uniform reporting of clinical outcomes makes recommendation of a target bicarbonate level difficult. Current guidelines must extrapolate from the few randomized trials, cohort studies, and expert consensus. The Kidney Disease Outcomes Quality Initiative (KDOQI) recommends a bicarbonate level $>22 \mathrm{mEq} / \mathrm{mL}$ in all patients. ${ }^{54}$ The UK Renal Association suggests that predialysis bicarbonate concentration should be between 18-24 mmol/L. ${ }^{55}$ While administration of bicarbonate is likely beneficial for patients on renal replacement therapy, overcorrection of metabolic acidosis can lead to alkalosis 
which has been associated with symptomatic hypotension in hemodialysis patients. ${ }^{56}$

Other studies have shown increased body weight and midarm muscle circumference in patients given higher concentration of bicarbonate in the diasylate. ${ }^{57}$ Correction of acidosis is also associated with increased albumin, reduction in normalized protein catabolic rate, and an increase in total essential amino acids. ${ }^{19,58-60}$ In hemodialysis patients, correction of metabolic acidosis reduces the increase of $\mathrm{PTH}$, reduces bone resorption and improves bone formation, as well as decreases TNF-alpha levels. ${ }^{61,62}$ These suggest that secondary to a decreased inflammatory state and improved nutritional status, patients with corrected metabolic acidosis have better outcomes.

\section{Contrast-medium induced nephropathy}

Contrast-medium induced nephropathy is likely the commonest cause of iatrogenic acute kidney injury and a common complication of iodinated contrast media exposure. ${ }^{5,63}$ The incidence of CIN is projected to increase given the increased use of contrast media for both diagnostic and interventional procedures. Patients with chronic kidney disease are at heightened risk for CIN, particularly those with stage 3 or greater renal dysfunction. ${ }^{7}$ It also results in increased morbidity, increased healthcare expenditure, and is associated with a higher mortality. ${ }^{64}$ The planned nature of the nephrotoxic insult posses a unique opportunity to implement strategies for preventing renal injury. While multiple interventions targeted at the prevention of CIN have been explored, minimizing contrast dose and adequate hydration remain the cornerstone of CIN prevention. Considerable controversy remains surrounding other potential preventative therapies such as sodium bicarbonate hydration around the time of contrast exposure.

The mechanisms leading to renal injury from contrast exposure remain poorly understood. This has undoubtedly contributed to the difficulties in identification of effective preventative therapies. Commonly proposed mechanisms of renal injury from contrast media exposure are renal vasoconstriction resulting in medullary ischemia, oxidative stress, and direct tubular nephrotoxicity. ${ }^{65,66}$ The vasoconstrictive effect may be mediated by an influx of calcium. In a canine model, administration of ionic hyperosmolar contrast media into the renal arteries causes an initial increase in blood flow followed by a prolonger period ( $>3$ hours) of vasoconstriction. ${ }^{67}$ When animals were pretreated with T-type calcium channel blockers (diltiazem or verapamil) the vasoconstrictive response was markedly attenuated. Other studies have investigated the role of vasoconstrictors such as endothelin and adenosine in the pathogenesis of CIN. Fujisaki et al observed higher urinary endothelin levels in patients with chronic renal failure undergoing cardiac catheterization. ${ }^{68}$ The intense vasoconstrictive response may contribute to the release of reactive oxygen species such as the superoxide ion. In patients with CKD, the generation of reactive oxygen species may exceed the antioxidant reserve resulting in CIN. ${ }^{69,70}$ As our understanding of the pathogenesis of CIN improves, it is likely that novel therapies will be introduced. ${ }^{71}$

\section{Prevention of contrast nephropathy, insights from randomized trials}

In 2005, sodium bicarbonate was introduced for the prevention of CIN with much excitement. ${ }^{72}$ In a single center study, 119 of planned 260 patients were randomized to either hydration with an intravenous sodium bicarbonate solution or $0.9 \%$ saline. Hydration was started one hour prior to contrast exposure and continued for six hours post-contrast exposure. A marked reduction in CIN was observed with sodium bicarbonate hydration. The CIN rate in the sodium bicarbonate and sodium chloride groups was $1.7 \%$ (1 patient) and $13.6 \%$ ( 8 patients), respectively $(P=0.02)$.

Two potential mechanisms were thought to underlie this profound treatment effect. The first involves renal vasoconstriction resulting in medullary ischemia. Reported duration of renal vasoconstriction in response to iodinated contrast-media exposure vary from less than two to greater than four hours..$^{65,73}$ It is hypothesized that hydration may attenuate this adverse effect of contrast exposure by reducing renin activation and loss of nitric oxide. However, the optimal duration and rate of hydration remain unknown. The second proposed mechanism thought to underlie this treatment effect is mediated by oxidant or free radical injury. It has been postulated that sodium bicarbonate administration may decrease generation of free radicals mediated by the Haber-Weiss reaction by increasing tubular $\mathrm{pH}$ since the reaction is most active at lower $\mathrm{pH}$ values. It has also been suggested that sodium bicarbonate hydration may scavenge the potent oxidant peroxynitrate, produced by the nitric oxide mediated pathway. ${ }^{74}$ Data in support of these mechanisms remains limited. Clearly, the pathophysiology of CIN is complex and not well understood.

Subsequent trials have shown mixed results. For example, the largest trials to date have not shown a statistically significant benefit for hydration with sodium bicarbonate. ${ }^{75-78}$ In a study by our group, 353 patients undergoing cardiac catheterization were randomized to hydration with sodium bicarbonate or sodium chloride. ${ }^{75}$ The population was at elevated risk for CIN. Inclusion criteria required an estimated glomerular filtration rate (eGFR) of less than $60 \mathrm{~mL} / \mathrm{min} / 1.73 \mathrm{~m}^{2}$ and at least one other CIN risk factor: age $>75$ years, hypertension, diabetes mellitus, or history of congestive heart failure. CIN 
was observed in $13.3 \%$ of the sodium bicarbonate group and $14.6 \%$ in the sodium chloride group $(P=0.82)$.

In another large trial, Maioli et al randomized 502 patients undergoing cardiac catheterization to hydration with sodium bicarbonate or sodium chloride. Inclusion criteria included $\mathrm{CrCl}$ less than $60 \mathrm{~mL} / \mathrm{min}^{76} \mathrm{CIN}$, defined as a $0.5 \mathrm{mg} / \mathrm{dL}$ increase in serum creatinine, was observed in $10 \%$ of the sodium bicarbonate group and $11.5 \%$ of the sodium chloride group $(P=0.60)$. Regardless of the definition of CIN, the rates were statistically similar with both fluid types. Another recent trial randomized 382 patients with diabetes scheduled to undergo cardiac catheterization to either sodium chloride for 12 hours pre- and postprocedure or to sodium bicarbonate for one hour before and six hours postprocedure. CIN was defined as either a $25 \%$ increase or $0.5 \mathrm{mg} / \mathrm{dL}$ absolute increase in serum creatinine. The CIN rate was in fact nonsignificantly greater in the sodium bicarbonate group compared to the sodium chloride group, $9.0 \%$ vs $5.3 \%$, respectively $(P=0.17)$.

\section{Prevention of contrast nephropathy, limitations of trial data}

There are likely multiple reasons for the conflicting data on the efficacy of sodium bicarbonate. A randomized trial provides the highest level of evidence on the efficacy, or lack thereof, for a particular therapy. However, trials must be conducted in a rigorous manner meeting certain quality metrics. An underpowered trial can be particularly challenging to interpret. ${ }^{79}$ Power analysis aids the investigator to design a trial that has a reasonable probability of rejecting the null hypothesis when in fact the null hypothesis is false. By convention, a study with at least $80 \%$ power is considered to be adequately powered with a chance of detecting a clinically significant effect when one exists. Underpowered trials inflate the likelihood of reaching false positive (ie, type I error) and false negative (ie, type II error) conclusions. ${ }^{80}$

In many randomized investigations of sodium bicarbonate, the type I and II errors are considerably inflated from their accepted values, possibly yielding false positive or false negatives results more frequently. The sample size calculation used by many trials testing the hypothesis that sodium bicarbonate is superior to sodium chloride for the prevention of CIN assumes a very large treatment effect. Specifically, assuming a CIN rate of $15 \%$ with sodium chloride and 5\% with sodium bicarbonate 280 to 300 patients would be required to detect a statistically significant difference with a power of $80 \%$ and $\alpha$ of $5 \%$. There are multiple trials in the literature now that have sample sizes

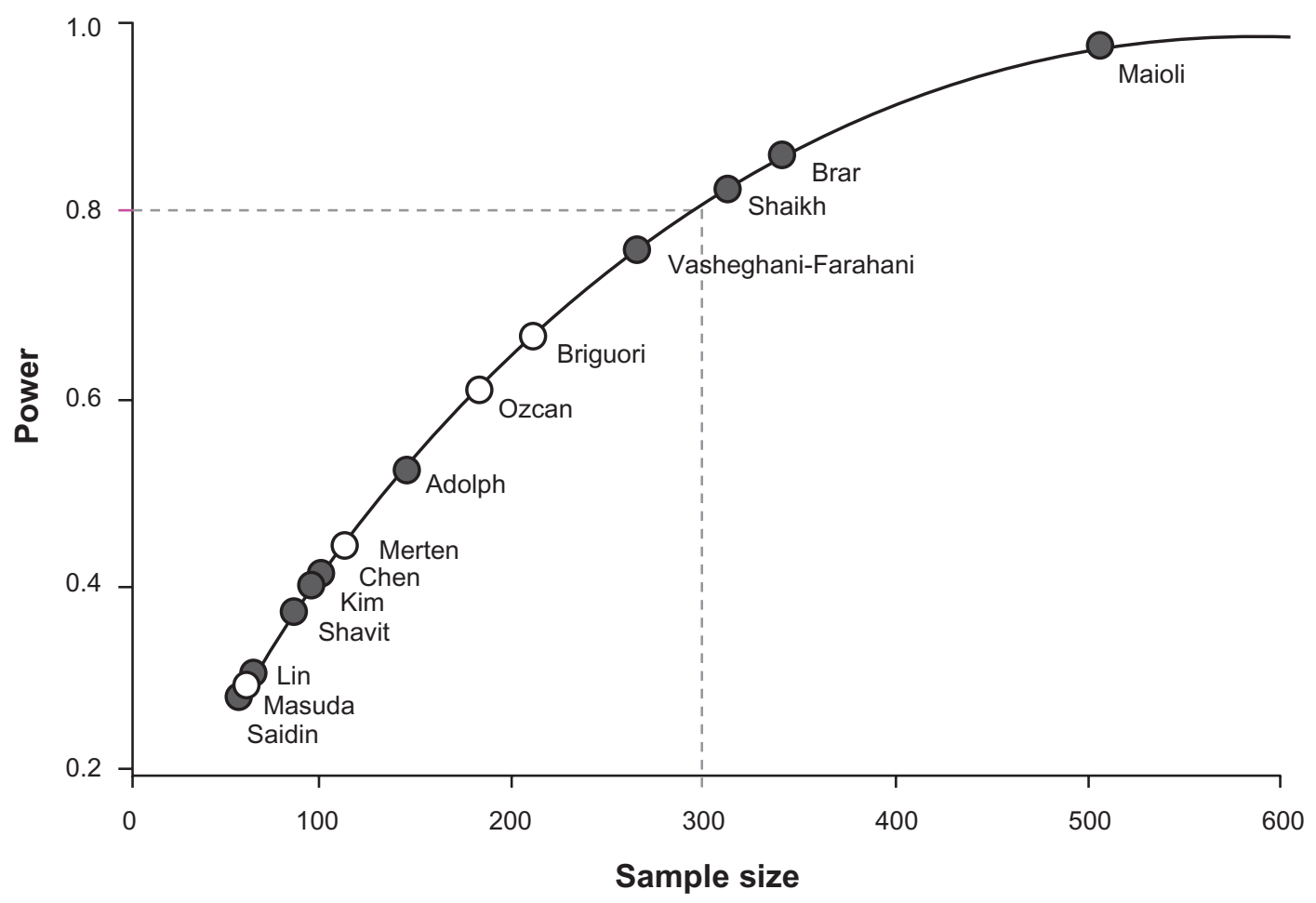

Figure I Power Curve. The graph shows the relationship between trial size and power. The dashed lines represent the sample size $(\mathrm{n}=300)$ necessary to achieve $80 \%$ power assuming an event rate of $15 \%$ in the sodium chloride group and $5 \%$ in the sodium bicarbonate group with an $\alpha$ of 0.05 . Closed circles represent trials where there was no difference between hydration with sodium bicarbonate or chloride for the prevention of contrast-medium induced nephropathy. Open circles represent trials where sodium bicarbonate was superior. Based upon these assumptions, all trials with $\geq 80 \%$ power did not observe any benefit for hydration with sodium bicarbonate. The trial by Heguilen et al is not shown since the trial enrolled only 18 subjects. ${ }^{97}$ 
considerably smaller than this and are likely underpowered or powered for a clinically unrealistic treatment effect. ${ }^{72,81-83}$ Figure 1 shows the relationship between power and study size. Based on the above sample size criteria, only three trials were adequately powered to detect a $10 \%$ difference between treatment groups. Moreover, each of these trials did not observe a statistically significant difference between hydration with sodium bicarbonate versus sodium chloride.

An additional problem is that some trials have been prematurely terminated without previously defined stopping rules..$^{72,81}$ Premature termination of randomized trials needs to be carefully considered. For example, the first trial of sodium bicarbonate to show a marked reduction in CIN was prematurely terminated after enrollment of 119 of the planned 260 patients. $^{72}$ One additional event in the sodium bicarbonate group would have yielded a statistically nonsignificant result. Furthermore, if the data are analyzed multiple times during the study, the likelihood of a chance finding is increased. This means that the significance level, $\alpha$, may need to be adjusted to compensate for the increased probability of a type I error due to multiple testing, something that was not done in these studies.

Other measures of trial quality are also commonly lacking or not well described in trials investigating sodium bicarbonate. For example, to date, only one trial has been double blinded. ${ }^{84}$ The results from this study were negative, suggesting no benefit for hydration with sodium bicarbonate. Most trials have been partially blinded with physicians but not patients able to determine the treatment assignment. If contrast volumes and intensity of follow-up are similar between treatment groups, partial blinding is less likely to have a profound impact since the outcome of interest, CIN, is based upon a qualitative laboratory measure. Another limitation is that most trials have been performed at single centers. Practice patterns may differ limiting the external validity or generalizability of the trial data.

\section{Prevention of contrast nephropathy, insights from meta-analysis}

Many of the issues raised about trial quality and outcomes have been investigated using meta-analytic techniques. ${ }^{85,86}$ However, conclusions from these studies have been conflicting and the quality of the analyses varied. ${ }^{87-94}$ One reason for the divergent conclusions are differences in interpretation of the extent of heterogeneity between trials and exploration of sources of heterogeneity. Trials that are very different or heterogeneous are not appropriate for pooling and a summary estimate from such analysis would be unreliable. Many of the current meta-analyses report the presence of statistically significant heterogeneity yet report summary estimates and fail to explore possible reasons for the heterogeneity. Understanding the sources of the heterogeneity may lead to clinically meaningful insights and enhance the interpretation of the trials in aggregate. Two recent meta-analyses explore potential sources of heterogeneity and provide insight into the disparate results of randomized trials. ${ }^{85,86}$

A recent comprehensive review of the literature identified 14 randomized trials performed between 2000 and 2009 (Table 1) ${ }^{85}$ Among these, seven studies have been published and seven remain unpublished. There is considerable heterogeneity between these trials that can be quantified statistically. The $\mathrm{I}^{2}$ statistic, the inconsistency in studies that cannot be explained by chance, was $48 \%(P$ heterogeneity $=0.02)$ and was largely explained by trial size and published status.

The observed treatment effect among some of the small trials has been quite extreme. The relative risk (RR) for five trials ranges from 0.12 to $0.33 .^{72,81-83,95}$. In contrast, the RR among the three largest studies ranges from 0.75 to 0.91 and was nonsignificant in each of the trials. ${ }^{75-77}$ This phenomenon where extreme treatment effects are limited to small trials has been characterized as the small study effect. ${ }^{96}$ Metaregression analyses are largely supportive. In a mixed-effects model, trials with larger standard errors (smaller studies) have greater estimated benefit with sodium bicarbonate. When the trials are stratified by size, the treatment benefit is limited to the small studies. This observation was corroborated in a subsequent meta-analysis. ${ }^{86}$

Using the sample size calculation described by Merten et al, three trials were characterized as large and eleven as small. The group of small and large trials each comprised $50 \%$ of the study population in the meta-analysis $(n=2290)$. In the small trials, the event rates in the sodium bicarbonate and sodium chloride groups were $6.7 \%$ and $13.5 \%$, respectively. The pooled RR and $95 \%$ confidence interval (CI) was $0.50(0.27$ to $0.93, P=0.03)$. This estimate is less reliable given the marked residual heterogeneity between the small trials $\left(\mathrm{I}^{2}=56 \% ; P\right.$ heterogeneity $\left.=0.01\right)$. Among the large trials, the cumulative incidence of CIN in the sodium bicarbonate and sodium chloride groups was $10.7 \%$ and $12.6 \%$, respectively. The pooled RR and 95\% CI were $0.85(0.62$ to $1.17, P=0.32$ ), suggesting no statistically significant difference between fluid types. There was also no evidence of clinical or statistical heterogeneity between the large trials $\left(I^{2}=0 \%\right)$. The event rates by fluid type in each trial are summarized in Figure 2. 
Table I Randomized controlled trials of sodium bicarbonate for the prevention of CIN

\begin{tabular}{|c|c|c|c|c|c|c|c|c|}
\hline Study & Year & $\begin{array}{l}\text { Sample } \\
\text { size }(n)\end{array}$ & Cl-AKI definition & Hydration protocol & $\begin{array}{l}\text { Contrast } \\
\text { type }\end{array}$ & $\begin{array}{l}\text { Baseline } \\
\text { creatinine } \\
(\mathrm{mg} / \mathrm{dL})\end{array}$ & $\begin{array}{l}\text { Age } \\
(y r)\end{array}$ & $\begin{array}{l}\text { Diabetes } \\
\text { (\%) }\end{array}$ \\
\hline Merten $^{72}$ & 2004 & 119 & $\begin{array}{l}\text { Creatinine increase } \\
\text { of } \geq 25 \% \text { within } 2 d\end{array}$ & $\begin{array}{l}3 \mathrm{~mL} / \mathrm{kg} \text { per } \mathrm{h} \text { for I } \mathrm{h} \\
\text { preprocedure and I } \mathrm{mL} / \mathrm{kg} \text { per } \mathrm{h} \\
\text { for } 6 \mathrm{~h} \text { postprocedure }\end{array}$ & $\begin{array}{l}\text { Low osmolar } \\
\text { (iopamidol) }\end{array}$ & 1.78 & 68 & 48 \\
\hline Saidin 98 & 2006 & 57 & $\begin{array}{l}\text { Creatinine increase } \\
\text { of } \geq 25 \% \text { within } 72 \mathrm{~h}\end{array}$ & $\begin{array}{l}\text { Infusion started } 2 \mathrm{~h} \text { preprocedure } \\
\text { and for } 6 \mathrm{~h} \text { postprocedure. Rate not } \\
\text { reported. }\end{array}$ & - & - & 62 & - \\
\hline Briguori ${ }^{82}$ & 2007 & 219 & $\begin{array}{l}\text { Creatinine increase } \\
\text { of } \geq 25 \% \text { within } 48 \mathrm{~h}\end{array}$ & $\begin{array}{l}\text { Saline: I mL/kg per } \mathrm{h} \text { for } 12 \mathrm{~h} \text { pre- } \\
\text { and postprocedure. Bicarbonate: } \\
3 \mathrm{~mL} / \mathrm{kg} \text { per } \mathrm{h} \text { for I } \mathrm{h} \text { preprocedure, } \\
\mathrm{I} \mathrm{mL} / \mathrm{kg} \text { per } \mathrm{h} \text { during procedure, and } \\
6 \mathrm{~h} \text { postprocedure }\end{array}$ & $\begin{array}{l}\text { Iso-osmolar } \\
\text { (iodixanol) }\end{array}$ & 1.99 & 71 & 57 \\
\hline Chen 95 & 2007 & 105 & $\begin{array}{l}\text { Creatinine increase of } \\
\geq 0.5 \mathrm{mg} / \mathrm{dL} \text { within } 72 \mathrm{~h}\end{array}$ & $\begin{array}{l}2 \mathrm{~mL} / \mathrm{kg} \text { per h for } 6 \mathrm{~h} \text { preprocedure } \\
\text { and } 80 \mathrm{~mL} / \mathrm{kg} \text { per h for } 6 \mathrm{~h} \\
\text { postprocedure }\end{array}$ & $\begin{array}{l}\text { Low osmolar } \\
\text { (iohexol) }\end{array}$ & - & 7I & 36 \\
\hline $\mathrm{Kim}^{102}$ & 2007 & 100 & $\begin{array}{l}\text { Creatinine increase } \\
\text { of } \geq 25 \% \text { within } 48 \mathrm{~h}\end{array}$ & $\mathrm{ImL} / \mathrm{kg}$ per $\mathrm{h}$ pre- and postprocedure & $\begin{array}{l}\text { Iso-osmolar } \\
\text { (iodixanol) }\end{array}$ & 1.1 & - & - \\
\hline Ozcan $^{83}$ & 2007 & 176 & $\begin{array}{l}\text { Creatinine increase } \\
\text { of } \geq 25 \% \text { or }>0.5 \mathrm{mg} / \mathrm{dL} \\
\text { within } 48 \mathrm{~h}\end{array}$ & $\begin{array}{l}\mathrm{I} \mathrm{mL} / \mathrm{kg} \text { per } \mathrm{h} \text { for } 6 \mathrm{~h} \text { pre- and post } \\
\text { procedure }\end{array}$ & $\begin{array}{l}\text { Low osmolar } \\
\text { (ioxaglate) }\end{array}$ & 1.39 & 69 & 45 \\
\hline Masuda $^{81}$ & 2007 & 59 & $\begin{array}{l}\text { Creatinine increase of } \\
\geq 0.5 \mathrm{mg} / \mathrm{dL} \text { within } 2 \mathrm{~d}\end{array}$ & $\begin{array}{l}3 \mathrm{~mL} / \mathrm{kg} \text { per } \mathrm{h} \text { for I } \mathrm{h} \text { (if possible) } \\
\text { preprocedure and I } \mathrm{mL} / \mathrm{kg} \text { per } \mathrm{h} \\
\text { for } 6 \mathrm{~h} \text { postprocedure }\end{array}$ & $\begin{array}{l}\text { Low osmolar } \\
\text { (iopamidol) }\end{array}$ & 1.31 & 75 & 31 \\
\hline $\operatorname{Lin}^{100}$ & 2008 & 60 & $\begin{array}{l}\text { Creatinine increase } \\
\text { of } \geq 25 \% \text { within } 3 \mathrm{~d}\end{array}$ & $\begin{array}{l}3 \mathrm{~mL} / \mathrm{kg} \text { per } \mathrm{h} \text { for I } \mathrm{h} \text { preprocedure } \\
\text { and } 6 \mathrm{~h} \text { postprocedure }\end{array}$ & $\begin{array}{l}\text { Low osmolar } \\
\text { (iopamidol) }\end{array}$ & 0.84 & 47 & 24 \\
\hline Shavit ${ }^{101}$ & 2008 & 87 & $\begin{array}{l}\text { Creatinine increase } \\
\text { of } \geq 25 \% \text { within } 2 \mathrm{~d}\end{array}$ & $\begin{array}{l}\text { Saline: I mL/kg per h for } 12 \mathrm{~h} \\
\text { preprocedure only. Bicarbonate: } \\
3 \mathrm{~mL} / \mathrm{kg} \text { per h for I h preprocedure } \\
\text { and I } \mathrm{mL} / \mathrm{kg} \text { per h for } 6 \mathrm{~h} \\
\text { postprocedure }\end{array}$ & $\begin{array}{l}\text { Low osmolar } \\
\text { (iopamidol) }\end{array}$ & 1.8 & - & - \\
\hline Adolph ${ }^{84}$ & 2008 & 145 & $\begin{array}{l}\text { Creatinine increase of } \\
\geq 25 \% \text { or }>0.5 \mathrm{mg} / \mathrm{dL} \\
\text { within } 2 \mathrm{~d}\end{array}$ & $\begin{array}{l}2 \mathrm{~mL} / \mathrm{kg} \text { per } \mathrm{h} \text { for } 2 \mathrm{~h} \text { preprocedure. } \\
\mathrm{I} \mathrm{mL} / \mathrm{kg} \text { per } \mathrm{h} \text { during and for } 6 \mathrm{~h} \\
\text { postprocedure }\end{array}$ & $\begin{array}{l}\text { Iso-osmolar } \\
\text { (iodixanol) }\end{array}$ & 1.56 & 72 & 32 \\
\hline Heguilen ${ }^{97}$ & 2007 & 18 & $\begin{array}{l}\text { Creatinine increase of } \\
\geq 25 \% \text { within } 3 d\end{array}$ & $\begin{array}{l}3 \mathrm{~mL} / \mathrm{kg} \text { per h for I h preprocedure } \\
\text { and } 3 \mathrm{~mL} / \mathrm{kg} \text { per h for } 6 \mathrm{~h} \\
\text { postprocedure }\end{array}$ & $\begin{array}{l}\text { Iso-osmolar } \\
\text { (ioversol) }\end{array}$ & - & 67 & - \\
\hline Shaikh ${ }^{77}$ & 2007 & 320 & $\begin{array}{l}\text { Creatinine increase of } \\
\geq 25 \% \text { or }>0.5 \mathrm{mg} / \mathrm{dL} \\
\text { within } 48 \mathrm{~h}\end{array}$ & $\begin{array}{l}3 \mathrm{~mL} / \mathrm{kg} \text { per } \mathrm{h} \text { for I } \mathrm{h} \\
\text { preprocedure and I } \mathrm{mL} / \mathrm{kg} \text { per } \mathrm{h} \\
\text { for } 6 \mathrm{~h} \text { postprocedure }\end{array}$ & - & 1.77 & 70 & 45 \\
\hline $\mathrm{Brar}^{75}$ & 2008 & 353 & $\begin{array}{l}\text { Estimated GFR decrease } \\
\text { of } \geq 25 \% \text { within } 4 \mathrm{~d}\end{array}$ & $\begin{array}{l}3 \mathrm{~mL} / \mathrm{kg} \text { per } \mathrm{h} \text { for I h preprocedure } \\
\text { and } 1.5 \mathrm{~mL} / \mathrm{kg} \text { per h during and } 4 \mathrm{~h} \\
\text { postprocedure }\end{array}$ & $\begin{array}{l}\text { Low osmolar } \\
\text { (ioxilan) }\end{array}$ & 1.5 & 71 & 44 \\
\hline Maioli ${ }^{76}$ & 2008 & 502 & $\begin{array}{l}\text { Creatinine increase of } \\
\geq 0.5 \mathrm{mg} / \mathrm{dL} \text { within } 5 \mathrm{~d}\end{array}$ & $\begin{array}{l}\text { Saline: I mL/kg per h for } 12 \mathrm{~h} \text { pre- } \\
\text { and postprocedure. Bicarbonate: } \\
3 \mathrm{~mL} / \mathrm{kg} \text { per h for I h preprocedure } \\
\text { and I } \mathrm{mL} / \mathrm{kg} \text { per } \mathrm{h} \text { for } 6 \mathrm{~h} \\
\text { postprocedure }\end{array}$ & $\begin{array}{l}\text { Iso-osmolar } \\
\text { (iodixanol) }\end{array}$ & 1.2 & 74 & 24 \\
\hline $\begin{array}{l}\text { Vasheghani- } \\
\text { Farahani }\end{array}$ & 2009 & 265 & $\begin{array}{l}\text { Creatinine increase of } \\
\geq 25 \% \text { or }>0.5 \mathrm{mg} / \mathrm{dL} \\
\text { within } 48 \mathrm{~h}\end{array}$ & $\begin{array}{l}3 \mathrm{~mL} / \mathrm{kg} \text { per } \mathrm{h} \text { for I } \mathrm{h} \\
\text { preprocedure and } \mathrm{I} \mathrm{mL} / \mathrm{kg} \text { per } \mathrm{h} \text { for } \\
6 \mathrm{~h} \text { postprocedure }\end{array}$ & $\begin{array}{l}\text { Low osmolar } \\
\text { (iohexol) }\end{array}$ & 1.64 & 63 & 26 \\
\hline $\mathrm{Kim}^{78}$ & 2010 & 382 & $\begin{array}{l}\text { Creatinine increase of } \\
\geq 25 \% \text { or }>0.5 \mathrm{mg} / \mathrm{dL} \\
\text { within } 48 \mathrm{~h}\end{array}$ & $\begin{array}{l}\text { Saline: I mL/kg/h for } 12 \mathrm{~h} \text { pre- } \\
\text { and postprocedure. Bicarbonate: } \\
3 \mathrm{~mL} / \mathrm{kg} \text { for I hr preprocedure and } \\
1 \mathrm{~mL} / \mathrm{kg} / \mathrm{hr} \text { during and } 6 \mathrm{~h} \\
\text { postprocedure }\end{array}$ & $\begin{array}{l}\text { Iso-osmolar } \\
\text { (iodixanol) }\end{array}$ & 1.5 & 68 & $100 \%$ \\
\hline
\end{tabular}

Abbreviations: $\mathrm{Cl}-\mathrm{AKI}$, contrast induced-acute kidney injury; CIN, contrast-medium induced nephropathy. 


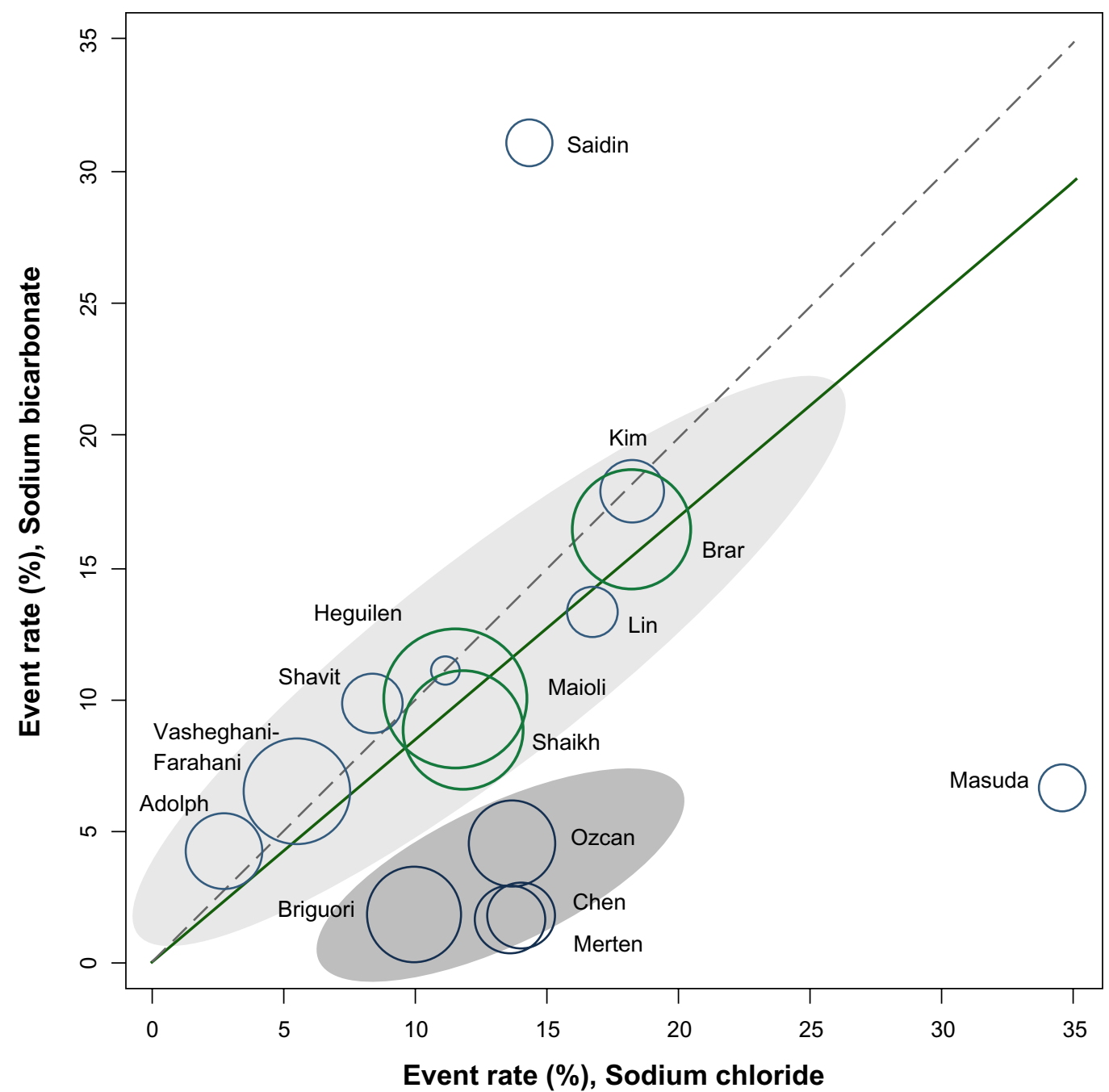

Figure 2 Modified L'Abbe plot of contrast nephropathy rates by trial. The plot shows the event rate of contrast induced nephropathy in the sodium bicarbonate and sodium chloride groups from randomized trials. The area of each circle is inversely proportional to the study size. The dotted line represents the no-effect line with identical event rates in both groups. Solid circles represent studies characterized as large (sample size $>300$ subjects). The solid line represents the pooled risk ratio of 0.85 as observed in the large trials. The shaded areas represent two groups of studies: (I) none or marginal benefit with sodium bicarbonate [light gray] and (2) marked benefit with sodium bicarbonate [dark gray].

\section{Conclusion}

The bicarbonate ion plays a critical role in the maintenance of acid/base homeostasis. The administration of bicarbonate can help correct acidemia and disorders of muscle and bone metabolism. More recently, sodium bicarbonate hydration has been proposed for the prevention of iodinated contrastmedia associated acute kidney injury. The initial enthusiasm surrounding sodium bicarbonate as an effective therapy for the prevention of contrast medium-induced nephropathy has largely dissipated due to the subsequent publication of negative trials. However, the literature remains conflicting due to the presence of multiple small positive randomized trials. As shown in a recent meta-analysis, smaller trials tended to be of lower quality and observed exaggerated treatment effects. Larger trials investigating sodium bicarbonate tend to be of higher methodological quality and have not shown a statistically significant benefit. Currently, there does not appear to be ample evidence to support the routine administration of sodium bicarbonate for the prevention of CIN. Nevertheless, sodium bicarbonate hydration has not been associated with an increase in adverse events. Therefore, hydration with sodium bicarbonate is safe but the efficacy remains in question. Furthermore, the treatment effect of sodium bicarbonate, if any, is likely considerably smaller than that observed in many of the small randomized trials. For example, a trial powered to detect a more modest $15 \%$ reduction in CIN rates would require 7000 to 9000 patients.

\section{Disclosures}

The authors report no conflicts of interest in this work. 


\section{References}

1. Mitch WE. Metabolic and clinical consequences of metabolic acidosis. J Nephrol. 2006;19 Suppl 9:S70-S75.

2. Kraut JA, Coburn JW. Bone, acid, and osteoporosis. $N$ Engl J Med. 1994;330(25):1821-1822.

3. Kraut JA, Mishler DR, Singer FR, Goodman WG. The effects of metabolic acidosis on bone formation and bone resorption in the rat. Kidney Int. 1986;30(5):694-700.

4. Mitch WE. Robert H Herman Memorial Award in Clinical Nutrition Lecture, 1997. Mechanisms causing loss of lean body mass in kidney disease. Am J Clin Nutr. 1998;67(3):359-366.

5. Weisbord SD, Mor MK, Resnick AL, et al. Prevention, incidence, and outcomes of contrast-induced acute kidney injury. Arch Intern Med. 2008;168(12):1325-1332.

6. McCullough PA, Adam A, Becker CR, et al. Epidemiology and prognostic implications of contrast-induced nephropathy. Am J Cardiol. 2006;98(6A):5K-13K.

7. McCullough PA, Adam A, Becker CR, et al. Risk prediction of contrast-induced nephropathy. Am J Cardiol. 2006;98(6A):27K-36K.

8. McCullough PA, Stacul F, Becker CR, et al. Contrast-Induced Nephropathy (CIN) Consensus Working Panel: executive summary. Rev Cardiovasc Med. 2006;7(4):177-197.

9. Coresh J, Selvin E, Stevens LA, et al. Prevalence of chronic kidney disease in the United States. JAMA. 2007;298(17):2038-2047.

10. Gumz ML, Lynch IJ, Greenlee MM, Cain BD, Wingo CS. The renal H+-K+-ATPases: physiology, regulation, and structure. Am J Physiol Renal Physiol. 2010;298(1):F12-F21.

11. Snyder JJ, Foley RN, Collins AJ. Prevalence of CKD in the United States: a sensitivity analysis using the National Health and Nutrition Examination Survey (NHANES) 1999-2004. Am J Kidney Dis. 2009; 53(2):218-228.

12. Thilly N, Boini S, Kessler M, Briancon S, Frimat L. Chronic kidney disease: appropriateness of therapeutic management and associated factors in the AVENIR study. J Eval Clin Pract. 2009;15(1):121-128.

13. Kalantar-Zadeh K, Mehrotra R, Fouque D, Kopple JD. Metabolic acidosis and malnutrition-inflammation complex syndrome in chronic renal failure. Semin Dial. 2004;17(6):455-465.

14. Tizianello A, De Ferrari G, Garibotto G, Gurreri G, Robaudo C. Renal metabolism of amino acids and ammonia in subjects with normal renal function and in patients with chronic renal insufficiency. J Clin Invest. 1980;65(5):1162-1173.

15. Dass PD, Kurtz I. Renal ammonia and bicarbonate production in chronic renal failure. Miner Electrolyte Metab. 1990;16(5):308-314.

16. Goodman AD, Lemann J Jr, Lennon EJ, Relman AS. Production, excretion, and net balance of fixed acid in patients with renal acidosis. $J$ Clin Invest. 1965;44:495-506.

17. Schwartz WB, Hall PW III, Hays RM, Relman AS. On the mechanism of acidosis in chronic renal disease. J Clin Invest. 1959;38(1 Pt 1):39-52.

18. Kraut JA, Kurtz I. Metabolic acidosis of CKD: diagnosis, clinical characteristics, and treatment. Am J Kidney Dis. 2005;45(6):978-993.

19. Verove C, Maisonneuve N, El Azouzi A, Boldron A, Azar R. Effect of the correction of metabolic acidosis on nutritional status in elderly patients with chronic renal failure. J Ren Nutr. 2002;12(4):224-228.

20. Ballmer PE, McNurlan MA, Hulter HN, Anderson SE, Garlick PJ, Krapf R. Chronic metabolic acidosis decreases albumin synthesis and induces negative nitrogen balance in humans. J Clin Invest. 1995;95(1):39-45.

21. Mitch WE, Du J, Bailey JL, Price SR. Mechanisms causing muscle proteolysis in uremia: the influence of insulin and cytokines. Miner Electrolyte Metab. 1999;25(4-6):216-219.

22. Lofberg E, Wernerman J, Anderstam B, Bergstrom J. Correction of acidosis in dialysis patients increases branched-chain and total essential amino acid levels in muscle. Clin Nephrol. 1997;48(4):230-237.

23. Bailey JL, Wang X, England BK, Price SR, Ding X, Mitch WE. The acidosis of chronic renal failure activates muscle proteolysis in rats by augmenting transcription of genes encoding proteins of the ATPdependent ubiquitin-proteasome pathway. J Clin Invest. 1996;97(6): $1447-1453$.
24. May RC, Kelly RA, Mitch WE. Mechanisms for defects in muscle protein metabolism in rats with chronic uremia. Influence of metabolic acidosis. J Clin Invest. 1987;79(4):1099-1103.

25. Leal VO, Delgado AG, Leite M Jr, Mitch WE, Mafra D. Influence of renal function and diet on acid-base status in chronic kidney disease patients. J Ren Nutr. 2009;19(2):178-182.

26. Clase CM, Kiberd BA, Garg AX. Relationship between glomerular filtration rate and the prevalence of metabolic abnormalities: results from the Third National Health and Nutrition Examination Survey (NHANES III). Nephron Clin Pract. 2007;105(4):c178-c184.

27. Movilli E, Bossini N, Viola BF, et al. Evidence for an independent role of metabolic acidosis on nutritional status in haemodialysis patients. Nephrol Dial Transplant. 1998;13(3):674-678.

28. Eustace JA, Astor B, Muntner PM, Ikizler TA, Coresh J. Prevalence of acidosis and inflammation and their association with low serum albumin in chronic kidney disease. Kidney Int. 2004;65(3):1031-1040.

29. Krieger NS, Sessler NE, Bushinsky DA. Acidosis inhibits osteoblastic and stimulates osteoclastic activity in vitro. Am J Physiol. 1992;262 (3 Pt 2):F442-F448.

30. Coe FL, Firpo JJ Jr, Hollandsworth DL, Segil L, Canterbury JM, Reiss E. Effect of acute and chronic metabolic acidosis on serum immunoreactive parathyroid hormone in man. Kidney Int. 1975;8(4):263-273.

31. Kraut JA. Disturbances of acid-base balance and bone disease in endstage renal disease. Semin Dial. 2000;13(4):261-266.

32. Lemann J Jr, Bushinsky DA, Hamm LL. Bone buffering of acid and base in humans. Am J Physiol Renal Physiol. 2003;285(5):F811-F832.

33. Martin KJ, Freitag JJ, Bellorin-Font E, Conrades MB, Klahr S, Slatopolsky E. The effect of acute acidosis on the uptake of parathyroid hormone and the production of adenosine 3',5'-monophosphate by isolated perfused bone. Endocrinology. 1980;106(5): 1607-1611.

34. Gadola L, Noboa O, Marquez MN, et al. Calcium citrate ameliorates the progression of chronic renal injury. Kidney Int. 2004;65(4): 1224-1230.

35. Nath KA, Hostetter MK, Hostetter TH. Pathophysiology of chronic tubulo-interstitial disease in rats. Interactions of dietary acid load, ammonia, and complement component C3. J Clin Invest. 1985;76(2): 667-675.

36. Torres VE, Cowley BD Jr, Branden MG, Yoshida I, Gattone VH. Long-term ammonium chloride or sodium bicarbonate treatment in two models of polycystic kidney disease. Exp Nephrol. 2001; 9(3): 171-180.

37. Halperin ML, Ethier JH, Kamel KS. Ammonium excretion in chronic metabolic acidosis: benefits and risks. Am J Kidney Dis. 1989;14(4): 267-271.

38. Gennari FJ, Hood VL, Greene T, Wang X, Levey AS. Effect of dietary protein intake on serum total $\mathrm{CO} 2$ concentration in chronic kidney disease: Modification of Diet in Renal Disease study findings. Clin J Am Soc Nephrol. 2006;1(1):52-57.

39. Mehrotra R, Kopple JD. Protein and energy nutrition among adult patients treated with chronic peritoneal dialysis. Adv Ren Replace Ther. 2003;10(3):194-212.

40. Bellocq A, Suberville S, Philippe C, et al. Low environmental $\mathrm{pH}$ is responsible for the induction of nitric-oxide synthase in macrophages. Evidence for involvement of nuclear factor-kappaB activation. $J$ Biol Chem. 1998;273(9):5086-5092.

41. Pitt B, Zannad F, Remme WJ, et al. The effect of spironolactone on morbidity and mortality in patients with severe heart failure. Randomized Aldactone Evaluation Study Investigators. N Engl J Med. 1999; 341(10):709-717.

42. Thatte HS, Rhee JH, Zagarins SE, et al. Acidosis-induced apoptosis in human and porcine heart. Ann Thorac Surg. 2004;77(4):1376-1383.

43. Whittaker J, Cuthbert C, Hammond V, Alberti KG. Impaired insulin binding to isolated adipocytes in experimental diabetic ketoacidosis. Diabetologia. 1981;21(6):563-568.

44. Brungger M, Hulter HN, Krapf R. Effect of chronic metabolic acidosis on thyroid hormone homeostasis in humans. Am J Physiol. 1997;272 (5 Pt 2):F648-F653. 
45. Bommer J, Locatelli F, Satayathum S, et al. Association of predialysis serum bicarbonate levels with risk of mortality and hospitalization in the Dialysis Outcomes and Practice Patterns Study (DOPPS). Am J Kidney Dis. 2004;44(4):661-671.

46. Kovesdy CP, Anderson JE, Kalantar-Zadeh K. Association of serum bicarbonate levels with mortality in patients with non-dialysis-dependent CKD. Nephrol Dial Transplant. 2009;24(4):1232-1237.

47. Rustom R, Grime JS, Costigan M, et al. Oral sodium bicarbonate reduces proximal renal tubular peptide catabolism, ammoniogenesis, and tubular damage in renal patients. Ren Fail. 1998;20(2):371-382.

48. Mathur RP, Dash SC, Gupta N, Prakash S, Saxena S, Bhowmik D. Effects of correction of metabolic acidosis on blood urea and bone metabolism in patients with mild to moderate chronic kidney disease: a prospective randomized single blind controlled trial. Ren Fail. 2006;28(1):1-5.

49. McSherry E, Morris RC Jr. Attainment and maintenance of normal stature with alkali therapy in infants and children with classic renal tubular acidosis. J Clin Invest. 1978;61(2):509-527.

50. Domrongkitchaiporn S, Pongskul C, Sirikulchayanonta V, et al. Bone histology and bone mineral density after correction of acidosis in distal renal tubular acidosis. Kidney Int. 2002;62(6):2160-2166.

51. de Brito-Ashurst I, Varagunam M, Raftery MJ, Yaqoob MM. Bicarbonate supplementation slows progression of CKD and improves nutritional status. J Am Soc Nephrol. 2009;20(9):2075-2084.

52. Roderick P, Willis NS, Blakeley S, Jones C, Tomson C. Correction of chronic metabolic acidosis for chronic kidney disease patients. Cochrane Database Syst Rev. 2007(1):CD001890.

53. Szeto CC, Wong TY, Chow KM, Leung CB, Li PK. Oral sodium bicarbonate for the treatment of metabolic acidosis in peritoneal dialysis patients: a randomized placebo-control trial. J Am Soc Nephrol. 2003;14(8):2119-2126.

54. KDOQI. National Kidney Foundation. Clinical practice guidelines for nutrition in chronic kidney disease. 2000; http://www.kidney. org/professionals/kdoqi/pdf/KDOQI2000NutritionGL.pdf. Accessed Apr 1, 2010.

55. UKRA. Renal Association. Treatment of adults and children with renal failure: standards and audit measures. 2009; http://www.renal.org/Clinical/ GuidelinesSection/Haemodialysis.aspx. Accessed Apr 1, 2010.

56. Gabutti L, Ferrari N, Giudici G, Mombelli G, Marone C. Unexpected haemodynamic instability associated with standard bicarbonate haemodialysis. Nephrol Dial Transplant. 2003;18(11):2369-2376.

57. Stein A, Moorhouse J, Iles-Smith H, et al. Role of an improvement in acid-base status and nutrition in CAPD patients. Kidney Int. 1997; 52(4):1089-1095.

58. Movilli E, Zani R, Carli O, et al. Correction of metabolic acidosis increases serum albumin concentrations and decreases kinetically evaluated protein intake in haemodialysis patients: a prospective study. Nephrol Dial Transplant. 1998;13(7):1719-1722.

59. Graham KA, Reaich D, Channon SM, et al. Correction of acidosis in CAPD decreases whole body protein degradation. Kidney Int. 1996; 49(5):1396-1400.

60. Kooman JP, Deutz NE, Zijlmans P, et al. The influence of bicarbonate supplementation on plasma levels of branched-chain amino acids in haemodialysis patients with metabolic acidosis. Nephrol Dial Transplant. 1997;12(11):2397-2401.

61. Lefebvre A, de Vernejoul MC, Gueris J, Goldfarb B, Graulet AM, Morieux C. Optimal correction of acidosis changes progression of dialysis osteodystrophy. Kidney Int. 1989;36(6):1112-1118.

62. Pickering WP, Price SR, Bircher G, Marinovic AC, Mitch WE, Walls J. Nutrition in CAPD: serum bicarbonate and the ubiquitin-proteasome system in muscle. Kidney Int. 2002;61(4):1286-1292.

63. Mehran R, Aymong ED, Nikolsky E, et al. A simple risk score for prediction of contrast-induced nephropathy after percutaneous coronary intervention: development and initial validation. J Am Coll Cardiol. 2004;44(7):1393-1399.

64. Weisbord SD, Chen H, Stone RA, et al. Associations of increases in serum creatinine with mortality and length of hospital stay after coronary angiography. J Am Soc Nephrol. 2006;17(10):2871-2877.
65. Russo D, Minutolo R, Cianciaruso B, Memoli B, Conte G, De Nicola L. Early effects of contrast media on renal hemodynamics and tubular function in chronic renal failure. J Am Soc Nephrol. 1995;6(5): 1451-1458

66. Katholi RE, Woods WT Jr, Taylor GJ, et al. Oxygen free radicals and contrast nephropathy. Am J Kidney Dis. 1998;32(1):64-71.

67. Bakris GL, Burnett JC Jr. A role for calcium in radiocontrastinduced reductions in renal hemodynamics. Kidney Int. 1985;27(2): $465-468$.

68. Fujisaki K, Kubo M, Masuda K, et al. Infusion of radiocontrast agents induces exaggerated release of urinary endothelin in patients with impaired renal function. Clin Exp Nephrol. 2003;7(4):279-283.

69. Locatelli F, Canaud B, Eckardt KU, Stenvinkel P, Wanner C, Zoccali C. Oxidative stress in end-stage renal disease: an emerging threat to patient outcome. Nephrol Dial Transplant. 2003;18(7): 1272-1280.

70. Massy ZA, Nguyen-Khoa T. Oxidative stress and chronic renal failure: markers and management. J Nephrol. 2002;15(4):336-341.

71. Spargias K, Adreanides E, Demerouti E, et al. Iloprost prevents contrast-induced nephropathy in patients with renal dysfunction undergoing coronary angiography or intervention. Circulation. 2009; 120(18):1793-1799.

72. Merten GJ, Burgess WP, Gray LV, et al. Prevention of contrast-induced nephropathy with sodium bicarbonate: a randomized controlled trial. JAMA. 2004;291(19):2328-2334.

73. Tumlin JA, Wang A, Murray PT, Mathur VS. Fenoldopam mesylate blocks reductions in renal plasma flow after radiocontrast dye infusion: a pilot trial in the prevention of contrast nephropathy. Am Heart J. 2002;143(5):894-903.

74. Caulfield JL, Singh SP, Wishnok JS, Deen WM, Tannenbaum SR. Bicarbonate inhibits N-nitrosation in oxygenated nitric oxide solutions. J Biol Chem. 1996;271(42):25859-25863.

75. Brar SS, Shen AY, Jorgensen MB, et al. Sodium bicarbonate vs sodium chloride for the prevention of contrast medium-induced nephropathy in patients undergoing coronary angiography: a randomized trial. JAMA. 2008;300(9):1038-1046.

76. Maioli M, Toso A, Leoncini M, et al. Sodium bicarbonate versus saline for the prevention of contrast-induced nephropathy in patients with renal dysfunction undergoing coronary angiography or intervention. $J$ Am Coll Cardiol. 2008;52(8):599-604.

77. Shaikh F, Maddikunta R, Museitif R, et al. A prospective randomized trial comparing normal saline and sodium bicarbonate with or without $\mathrm{N}$-acetyleysteine for prevention of contrast-induced nephropathy. $\mathrm{Am}$ J Cardiol. 2007;100(8):122L-123L Suppl 121; abstract.

78. Kim Y-H. Preventive strategies of renal insufficiency in patients with diabetes undergoing intervention or arteriography. Paper presented at: American College of Cardiology Scientific Sessions; March, 2010; Atlanta, GA.

79. Freiman JA, Chalmers TC, Smith H Jr, Kuebler RR. The importance of beta, the type II error and sample size in the design and interpretation of the randomized control trial. Survey of 71 "negative" trials. N Engl J Med. 1978;299(13):690-694.

80. Halpern SD, Karlawish JH, Berlin JA. The continuing unethical conduct of underpowered clinical trials. JAMA. 2002;288(3):358-362.

81. Masuda M, Yamada T, Mine T, et al. Comparison of usefulness of sodium bicarbonate versus sodium chloride to prevent contrast-induced nephropathy in patients undergoing an emergent coronary procedure. Am J Cardiol. 2007;100(5):781-786.

82. Briguori C, Airoldi F, D'Andrea D, et al. Renal Insufficiency Following Contrast Media Administration Trial (REMEDIAL): a randomized comparison of 3 preventive strategies. Circulation. 2007;115(10):1211-1217.

83. Ozcan EE, Guneri S, Akdeniz B, et al. Sodium bicarbonate, $\mathrm{N}$-acetylcysteine, and saline for prevention of radiocontrast-induced nephropathy. A comparison of 3 regimens for protecting contrast-induced nephropathy in patients undergoing coronary procedures. A single-center prospective controlled trial. Am Heart J. 2007;154(3):539-544. 
84. Adolph E, Holdt-Lehmann B, Chatterjee T, et al. Renal Insufficiency Following Radiocontrast Exposure Trial (REINFORCE): a randomized comparison of sodium bicarbonate versus sodium chloride hydration for the prevention of contrast-induced nephropathy. Coron Artery Dis. 2008;19(6):413-419.

85. Brar SS, Hiremath S, Dangas G, Mehran R, Brar SK, Leon MB. Sodium bicarbonate for the prevention of contrast induced-acute kidney injury: a systematic review and meta-analysis. Clin J Am Soc Nephrol. 2009;4(10):1584-1592.

86. Zoungas S, Ninomiya T, Huxley R, et al. Systematic review: sodium bicarbonate treatment regimens for the prevention of contrast-induced nephropathy. Ann Intern Med. 2009;151(9):631-638.

87. Kunadian V, Zaman A, Spyridopoulos I, Qiu W. Sodium bicarbonate for the prevention of contrast induced nephropathy: a meta-analysis of published clinical trials. Eur J Radiol. Epub 2010 Jan 12.

88. Hoste EA, De Waele JJ, Gevaert SA, Uchino S, Kellum JA. Sodium bicarbonate for prevention of contrast-induced acute kidney injury: a systematic review and meta-analysis. Nephrol Dial Transplant. 2010; 25(3):747-758.

89. Meier P, Ko DT, Tamura A, Tamhane U, Gurm HS. Sodium bicarbonatebased hydration prevents contrast-induced nephropathy: a meta-analysis. BMC Med. 2009;7:23.

90. Kanbay M, Covic A, Coca SG, Turgut F, Akcay A, Parikh CR. Sodium bicarbonate for the prevention of contrast-induced nephropathy: a meta-analysis of 17 randomized trials. Int Urol Nephrol. 2009; 41(3):617-627.

91. Joannidis M, Schmid M, Wiedermann CJ. Prevention of contrast mediainduced nephropathy by isotonic sodium bicarbonate: a meta-analysis. Wien Klin Wochenschr. 2008;120(23-24):742-748.

92. Navaneethan SD, Singh S, Appasamy S, Wing RE, Sehgal AR. Sodium bicarbonate therapy for prevention of contrast-induced nephropathy: a systematic review and meta-analysis. Am J Kidney Dis. 2009;53(4): 617-627.

93. Ho KM, Morgan DJ. Use of isotonic sodium bicarbonate to prevent radiocontrast nephropathy in patients with mild pre-existing renal impairment: a meta-analysis. Anaesth Intensive Care. 2008;36(5): 646-653.
94. Hogan SE, L'Allier P, Chetcuti S, et al. Current role of sodium bicarbonate-based preprocedural hydration for the prevention of contrastinduced acute kidney injury: a meta-analysis. Am Heart J. 2008; 156(3):414-421.

95. Chen H, Wu H, He Q, Chen H, Mao Y. Comparison of sodium bicarbonate and sodium chloride as strategies for preventing contrast nephropathy. J Am Soc Nephrol. 2007;18:817A (abstract).

96. Bagshaw SM, McAlister FA, Manns BJ, Ghali WA. Acetylcysteine in the prevention of contrast-induced nephropathy: a case study of the pitfalls in the evolution of evidence. Arch Intern Med. 2006;166(2): 161-166.

97. Heguilen R, Liste A, Rosende G, et al. Prevention of contrast-induced nephropathy: volume expansion, $\mathrm{N}$-acethylcysteine or both? Results from a pilot study. Nephrol Dial Transplant. 2007;22:vi54 (Suppl 56 abstract).

98. Saidin R, Zainudin S, Norella CT, Maskon O, Saaidin NF, Shah Sa Intravenous sodium bicarbonate versus normal saline infusion as prophylaxis against contrast nephropathy in patients with chronic kidney disease undergoing coronary angiography or angioplasty. J Am Soc Nephrol. 2006;17:766A (abstract).

99. Vasheghani-Farahani A, Sadigh G, Kassaian SE, et al. Sodium bicarbonate plus isotonic saline versus saline for prevention of contrast-induced nephropathy in patients undergoing coronary angiography: a randomized controlled trial. Am J Kidney Dis. 2009; 54(4):610-618.

100. Lin M, Sabeti M, Iskander E, Malhotra N, Pham PT, Pham PC. Prevention of contrast nephropathy with sodium bicarbonate. J Am Soc Nephrol. 2007;18:959A (abstract).

101. Shavit L, Korenfeld R, Butnaru A, Slotki I. Sodium bicarbonate compared to sodium chloride and oral $\mathrm{N}$-acetylcysteine for the prevention of contrast induced nephropathy in patients with advanced chronic kidney disease. J Am Soc Nephrol. 2008;19:787A (abstract).

102. Kim G, Kim K, Shin J, Lee CH, Kang CM. Hydration with sodium bicarbonate for the prevention of radiocontrast-induced nephropathy. Nephrol Dial Transplant. 2007;22:vi49 (Suppl 46; abstract).
Nutrition and Dietary Supplements

\section{Publish your work in this journal}

Nutrition and Dietary Supplements is an international, peer-reviewed, open access journal focusing on research into nutritional requirements in health and disease, impact on metabolism and the identification and optimal use of dietary strategies and supplements necessary for normal growth and development. The journal welcomes papers covering

\section{Dovepress}

original research, basic science, clinical \& epidemiological studies, reviews and evaluations, guidelines, expert opinion and commentary, case reports and extended reports. The manuscript management system is completely online and includes a very quick and fair peer-review system, which is all easy to use. 